\title{
EVALUATION OF THE SERUM BIOCHEMISTRY AND HISTOPATHOLOGY OF KIDNEY AND BLADDER OF DOGS WITH Leishmania sp. IN THEIR URINE
}

\author{
AVALIAÇÃO DA BIOQUÍMICA SÉRICA E DA HISTOPATOLOGIA DE RIM E \\ BEXIGA EM CÃES COM Leishmania sp. NA URINA
}

\author{
Joilson Ferreira BATISTA ${ }^{1}$; Barbara Laurice Araújo VERÇOSA ${ }^{2}$; \\ Michel Muálem de Moraes ALVES ${ }^{3}$; Fernanda Samara Barbosa ROCHA ${ }^{\mathbf{1}}$; \\ Rayssa Maria de Araújo CARVALHO ${ }^{4}$; Maria das Graças PRIANTI ${ }^{1}$; \\ Bárbara Cristina Silva Holanda QUEIROZ ${ }^{5}$; Carlos Henrique Nery COSTA ${ }^{6}$; \\ Ivete Lopes de MENDONÇA ${ }^{1}$
}

1. Universidade Federal do Piauí, Centro de Ciências Agrárias, Programa de Pós-Graduação em Ciência Animal, Teresina, Piauí, Brasil. joilsonvet@gmail.com; 2. Universidade Federal de Minas Gerais, Instituto de Ciências Biológicas, Departamento de Patologia Geral, Belo Horizonte, Minas Gerais, Brasil; 3. Universidade Federal do Piauí, Centro de Ciências Agrárias, Departamento de Morfofisiologia Veterinária, Teresina, Piauí, Brasil; 4. Centro Universitário Unifacid, Teresina, Piauí, Brasil; 5. Universidade Federal do Rio Grande do Norte, Centro de Ciências da Saúde, Programa de Pós-Graduação em Ciências Farmacêuticas, Natal, Rio Grande do Norte, Brasil; 6. Laboratório de Leishmanioses, Instituto de Doenças Tropicais "Natan Portella", Teresina, Brasil.

\begin{abstract}
The visceral establishment of Leishmania infantum in dogs may result in kidney and bladder tissue injury, with L. infantum ending up in urine. This study therefore aimed at investigating the presence of Leishmania sp. in urinary sediments, and correlating the results with those from renal and bladder serum biochemistry and histopathology. Thirty dogs with negative Nested-Polymerase Chain Reaction (PCR) for E. canis were used in the experiment, and were divided into three groups: control group (10 dogs), neither leishmaniasis nor clinical changes; group I (15 dogs), leishmaniasis but no Leishmania sp. in urine; and group II (5 dogs), leishmaniasis, as well as Leishmania sp. in urine. All animals were submitted to clinical, serological, and parasitological diagnosis for leishmaniasis, biochemical exams, and kidney and bladder histopathology. The parasite was also detected in the bladder imprint of one group II dog. Group II dogs presented with very low albumin concentrations, low albumin/globulin ratios, and kidney and bladder lesions. In the kidneys, hydropic degeneration, thickened Bowman's capsule, and thickening of the tubular capsule were detected in all dogs with positive urinary sediment. However, no significant difference in these renal changes was observed between groups. The intensity and distribution of bladder inflammatory infiltrates were significantly (p-value $<0.05$, Kruskal-Wallis' and Dunn's tests) higher in group II dogs, compared with those of the other groups. The presence of Leishmania sp. in the urine of infected dogs appeared to be related to low serum albumin concentrations and more severe bladder lesions.
\end{abstract}

KEYWORDS: Histopathology. Leishmaniasis. Serum biochemistry. Urine.

\section{INTRODUCTION}

Depending on the immune status of each dog, natural infection with Leishmania infantum can result in three levels of clinical responses: asymptomatic, mildly symptomatic, and polisymptomatic (GIUNCHETTI et al., 2006; QUEIROZ et al., 2010; MENDONÇA et al., 2015a). This diversity of clinical symptoms represents a serious challenge during the diagnosis of canine visceral leishmaniasis (CVL), as does the difficulty in obtaining a both highly sensitive and specific diagnostic test, mainly in endemic areas, where serological tests present substandard performance in diagnosing infected and reservoir dogs (CASTRO et al., 2012; SANTOS et al., 2014; MENDONÇA, et al., 2017a; MENDONÇA et al., 2017b). Late diagnosis enables parasite spread and expansion, increasing the possibility for multi-organ lesion development, and altering biochemical parameters.

When assessing the serum biochemistry of CVL dogs, it is common to detect hypoalbuminemia, hypergammaglobulinemia, inversion in the albumin/globulin ratio, increased urea and creatinine concentrations, and increased liver enzyme (alanine aminotransferase). Biochemical quantifications are of great value when analyzing organ (liver and kidney) functionality and possible pathology (LOPES; BIONDO; SANTOS, 2007; MENDONÇA; BATISTA; ALVES, 2015b; COSTA et al., 2015). 
Renal alterations are quite common in CVL (FILHO; FERREIRA; COSTA, 2003; CAMARGO et al., 2006; GOMES et al., 2008). Interstitial nephritis and tubular alterations are common in CVL dogs, varying from mild inflammatory infiltrates, to severe lesions and loss of function (GOMES et al., 2008; COSTA et al., 2003).

The presence of Leishmania sp. in urine can be related to the severity of the renal lesions, necessitating kidney impairment evaluation via biochemical measurements. It is also necessary to perform histopathology, given that biochemical parameters only detect kidney injury when it affects over $75 \%$ of the function of both kidneys (ALBUQUERQUE et al., 2008; ARESU et al., 2013).

In bladder tissues, previous studies found the occurrence of cystitis in dogs with positive serology for leishmaniasis, and the main observed inflammatory infiltrates were lymphohistoplasmacytic and lymphoplasmacytic, followed by macrophage infiltration. Leishmania sp. antigens have also been immunostained in bladder tissues (SANTOS et al., 2013).

Leishmania sp. has been reported in the urine of dogs and humans (MEBRAHTU et al., 1993; RIERA; VALDARES, 1996; MENDONÇA; BATISTA; ALVES, 2015b). However, consequences of the clinical alterations and lesions induced by the parasite on the urine of VL dogs remain unknown.

This study aimed to evaluate the presence of Leishmania sp. in urinary sediments, and correlating the results with the biochemical parameters and kidney and bladder histopathological injuries in dogs naturally infected with Leishmania sp., in order to identify possible changes favoring parasite occurrence in urinary sediment.

\section{MATERIAL AND METHODS}

\section{Ethical Consideration}

The study was performed in the Animal Sanity Laboratory (LASAN) of the Universidade Federal do Piauí (UFPI), using a protocol approved by the Ethics Committee on Animal Experimentation ECAE / UFPI - No. 022/13.

\section{Sample Size}

Thirty domestic dogs of different breeds and ages, with negative Nested-Polymerase Chain Reaction (PCR) for E. canis, were used. They were divided into three groups: the control group, which consisted of 10 dogs without physical abnormalities suggestive of CVL, whose serological and parasitological tests were negative for leishmaniasis; group I, which consisted of 15 animals with Leishmania sp. in the bone marrow, popliteal lymph nodes, and/or skin, but not the urinary sediment; and group II, which consisted of 5 animals with Leishmania sp. in the bone marrow, popliteal lymph nodes, and/or skin, as well as the urinary sediment. The dogs were sacrificed to obtain their kidneys and bladders for histopathological tests. All dogs originated from the Control Center of Zoonoses, without previous clinical evaluation and tests for VL.

\section{Serological Tests and Biochemical Analyses}

To perform these tests, $10 \mathrm{~mL}$ of venous blood was collected from the jugular, using vacuum collection tubes without anticoagulant, to obtain serum for the TRDPP ${ }^{\circledR}$ CVL serological tests (BioManguinhos kit, Rio de Janeiro, Brazil), the immunosorbent assay (ELISA) - (Bio-Manguinhos kit, Rio de Janeiro, Brazil), and the serum quantifications of urea, creatinine, albumin, and total proteins, performed using the Lab Test Liquiform kit (Lagoa Santa, Minas Gerais, Brazil) and the semi-automatic biochemical analyzer (TP ANALYZER), Thermo Plate. The serological and biochemical tests were carried out following the manufacturer's instructions. The serum globulin concentration was calculated by subtracting albumain from the total protein. The results of the biochemical analyses were compared to the reference values described by Kaneko, Harvey and Bruss (1997).

\section{Parasitological Diagnosis for CVL}

\section{Culture and smear slide using samples of bone marrow, lymphnode, and damaged skin}

Bone marrow and lymph node punctures were performed with the aid of a $20 \mathrm{~mL}$ syringe attached to a $40 \times 12 \mathrm{~mm}$ needle, and a $10 \mathrm{~mL}$ syringe attached to a $25 \times 7 \mathrm{~mm}$ needle, respectively. The obtained samples were plated on NNN culture medium enriched with Schneider's. The readings for Leishmania sp. promastigote forms were taken on the $5^{\text {th }}, 8^{\text {th }}, 10^{\text {th }}$, and $15^{\text {th }}$ day after seeding. The same bone marrow and lymph node samples were used in smear slides and stained using the Giemsa method, to investigate the Leishmania sp. amastigote forms. In dogs with skin lesion, a scrap was collected and stained using the Giemsa method.

\section{Culture and smear slide using urinary sediment}


Evaluation of the serum...

To investigate Leishmania sp. in the urine sediments, volumes ranging from 6 to $80 \mathrm{~mL}$ of urine were collected by cystocentesis. The samples were then centrifuged at $3,600 \mathrm{xg}$ for $20 \mathrm{~min}$, and the obtained sediments seeded in NNN culture medium supplemented with Schneider's, to identify Leishmania sp. promastigote forms. Readings were taken on the $5^{\text {th }}, 8^{\text {th }}, 10^{\text {th }}$, and $15^{\text {th }}$ day after seeding. Two microliters of urine sediment were spread on slides and stained using the Giemsa method, to investigate the Leishmania sp. amastigote forms.

\section{Tissue collection for cytology and histopathology}

The dogs were euthanized following the rules of the National Board of Animal Experimentation Control (CONCEA), Law No. 11,794 of 2008 , October $8^{\text {th }}$ and Resolution No. 1000, of May 11, 2012, and according to the following procedure: sedation with acepromazine $0.2 \%$ at a dose of $0.5 \mathrm{mg} / \mathrm{kg} / \mathrm{LW}$, general anesthesia with Ketamine chloride $10 \%$ at a dose of 15 $\mathrm{mg} / \mathrm{kg} / \mathrm{LW}$, and subsequent application of potassium chloride to $10 \%$ at a dose of $100 \mathrm{mg} / \mathrm{kg} / \mathrm{LW}$, both administered intravenously.

\section{Cytology}

Imprint slides were preapared with kidney and bladder tissues, and then fixed in methyl alcohol. After complete alcohol evaporation, staining was performed with Giemsa at a 1:5 dilution in distilled water, for $40 \mathrm{~min}$. The visualization was performed with a $100 \mathrm{x}$ optical microscope, to investigate Leishmania sp. amastigote forms.

\section{Histopathology}

About $2 \mathrm{~cm}$-thick kidney and bladder fragments, fixed in $10 \%$ buffered formalin were then dehydrated, diaphanized, and embedded in paraffin to form $5 \mu \mathrm{m}$-thick histological sections, which were partially performed in series. The sections were deparaffinizaed in xylene for $10 \mathrm{~min}$ and hydrated in decreasing concentrations of ethanol for $5 \mathrm{~min}$. The kidney sections were stained using hematoxylin and eosin (HE), Periodic Acid Schiff (PAS), and Masson trichrome, while the bladder sections underwent only HE, and were examined under a light microscope.

The intensity of the inflammatory infiltrates was rated on a scale from 0 to 4 , according to Tisher and Brenner (1994) description and distribution ranging from 0 to 3 : where, $0=$ absent, $1=$ focal $(\mathrm{a}$ focal inflammatory infiltrate), $2=$ multifocal (more than one focal inflammatory infiltrate) and $3=$ diffuse (inflammatory infiltrate scattered in the
BATISTA et al.

whole or largely distributed in the sections). Degenerative changes and the location and cell type of the inflammatory infiltrate were classified only as absent or present.

\section{Nested-PCR for $E$. Canis}

A $200 \mu \mathrm{L}$ blood sample was subjected to DNA extraction using the commercial kit "QIAamp DNA Mini Kit -Qiagen", following the manufacturer's instructions. The Nested-PCR was performed using the following reagents: $10 \mathrm{x}$ PCR buffer, $50 \mathrm{mM} \mathrm{MgCl}_{2}, 10 \mathrm{mM}$ dNTP Mix, and Platinum TaqDNA Polymerase. In the first reaction, the primers used were EHO F - 5'AGAACGAACGCTGGCGGCAAGCC-3' e EHO $\mathrm{R}$ - 5'-CGTATTACCGCGGCTGCTGGC-3' (DAWSON et al., 1994), specific to the 16S rRNA segment of the genus Ehrlichia. In the second reaction, the primers ECA F 5' CAATTATTTATAGCCTCTGGCTATAGGAA 3' (YABSLEY et al., 2004) and ECA R - 5' CGTATTACCGCGGCTGCTGGC - 3' (DAWSON et al., 1994) specific to the 16S rRNA segment of $E$. canis were used. Amplification was performed in a "Life Pro Thermal Cycler" using the following temperature/time: initial denaturation step at $94^{\circ} \mathrm{C}$ for $10 \mathrm{~min}$, then 40 cycles of denaturation at $94^{\circ} \mathrm{C}$ for $60 \mathrm{~s}$, primer annealing at $60^{\circ} \mathrm{C}$ for $60 \mathrm{~s}$, and then primer extension at $72^{\circ} \mathrm{C}$ for $60 \mathrm{~s}$. The final step was primer extension at $72^{\circ} \mathrm{C}$ for $4 \mathrm{~min}$, and then maintainance at $4^{\circ} \mathrm{C}$ (BULLA et al., 2004). For the negative control, DNA from dogs known to be negative for Ehrlichia sp., were used. For the positive control, DNA samples from dogs known to be positive for E. canis and a DH82 cell culture DNA sample infected with E. canis, were used. The DNA amplicons were visualized after staining with ethidium bromide with the aid of a UV transilluminator (BioAgency). and photographed in photodocumenter (Bio - Imaging Systems).

\section{Statistical Analyses}

The number of clinical signs of groups I and II were compared using the Mann-Whitney test. To compare the biochemical parameters and the intensity and distribution of inflammatory infiltrates observed from kidney and bladder hitopathology tests (control, group I, and group II), Kruskal-Wallis $\mathrm{H}$ test, followed by Dunn's post test were performed. Degenerative changes observed in the kidney hitopathological test were compared between groups I and II, using Fisher's exact test. All tests admitted error probability of 5\% and were performed using the GramPad prism ${ }^{\circledR}$ version 5.0 (CA, USA).

\section{RESULTS}


Of the 30 dogs used, 20 were infected, with five having Leishmania sp. in their urine sediment cultures (Fig. 1A). Only one animal was positive in the bladder imprint (Fig. 1B), belonging to the group of dogs with urinary Leishmania sp. The kidney tissue imprints and urine sediment smears were negative for Leishmania sp..

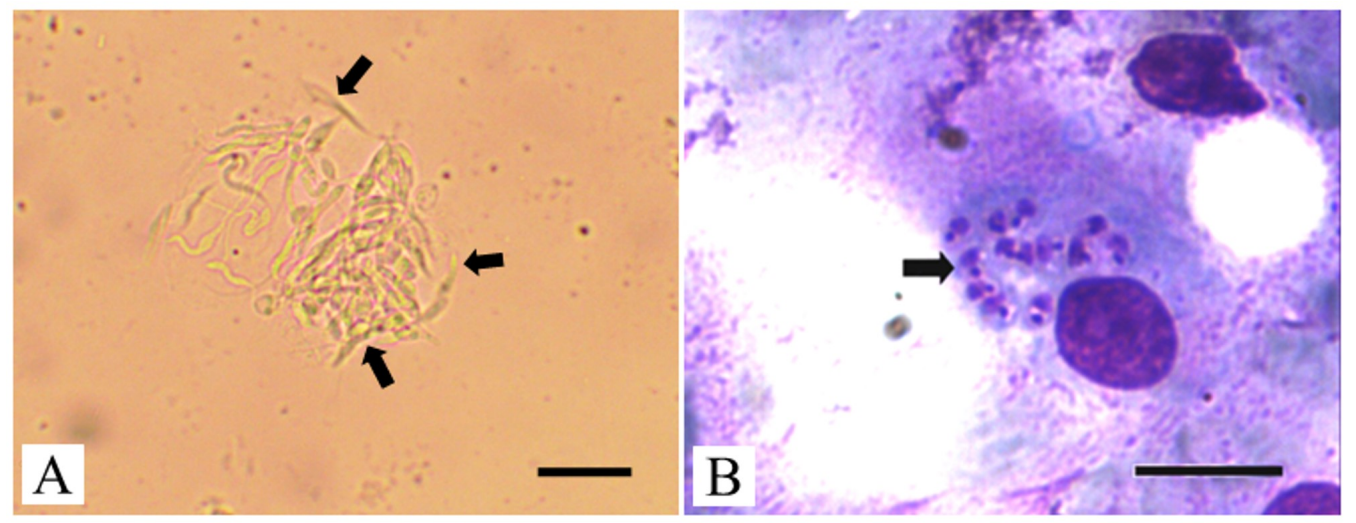

Figure 1. Infected dog with positive urine sediment culture (USC).

A - Leishmania sp. promastigotes in urine sediment culture (arrow). Culture medium NNN with Schneider's. Bar $=20 \mu \mathrm{m}$. Presence of amastigote from Leishmania sp. in macrophage cytoplasm, in bladder cell imprint (arrow). Giemsa dye. Bar = $10 \mu \mathrm{m}$.

Regarding the biochemical parameters, the values of albumin and the albumin/globulin ratio of animals with urinary Leishmania sp. were significantly lower ( $\mathrm{p}$-value $<0.05$, Kruskal-Wallis or Dunn's test) compared with those of infected dogs with negative urine sediments, and the control group
(Table 1). No significant difference was observed in the urea and creatinine parameters among the three groups of dogs studied (Table 1).

The five dogs with positive urine showed hypoalbuminemia, low albumin/globulin ratios, and $>4$ CVL-related clinical signs (Table 2).

Table 1. Serum biochemical quantifications of dogs of the control group; group of dogs infected with Leishmania sp., with negative urine sediment cultures; and group of dogs infected with Leishmania sp., having positive urine sediment cultures, with mean values (minimum-maximum)

\begin{tabular}{|c|c|c|c|c|}
\hline $\begin{array}{l}\text { Biochemical } \\
\text { Parameters }\end{array}$ & $\begin{array}{c}\text { Control } \\
\mathrm{n}=10\end{array}$ & $\frac{\text { Infected, Negative USC }}{\mathrm{n}=15}$ & $\begin{array}{c}\text { Infected, Positive USC } \\
\mathrm{n}=5\end{array}$ & $\begin{array}{c}\text { Reference } \\
\text { Values }\end{array}$ \\
\hline Urea $(\mathrm{mg} / \mathrm{dL})$ & $\begin{array}{c}49.4^{\mathrm{a}} \\
(17.9-175.5)\end{array}$ & $\begin{array}{c}56.3^{\mathrm{a}} \\
(11.7-283)\end{array}$ & $\begin{array}{c}68.2^{\mathrm{a}} \\
(27.5-217)\end{array}$ & $21.4-59.9$ \\
\hline Creatinine $(\mathrm{mg} / \mathrm{dL})$ & $\begin{array}{c}1.10^{\mathrm{a}} \\
(0.81-1.87)\end{array}$ & $\begin{array}{c}1.06^{\mathrm{a}} \\
(0.52-2.9)\end{array}$ & $\begin{array}{c}0.91^{\mathrm{a}} \\
(0.58-1.36)\end{array}$ & $0.50-1.50$ \\
\hline Total Proteins $(\mathrm{g} / \mathrm{dL})$ & $\begin{array}{c}8.3^{\mathrm{a}} \\
(6.0-13.4)\end{array}$ & $\begin{array}{c}10.2^{\mathrm{a}} \\
(6.1-16.0)\end{array}$ & $\begin{array}{c}9.3^{\mathrm{a}} \\
(3.5-16.4)\end{array}$ & $5.40-7.10$ \\
\hline Albumin (g/dL) & $\begin{array}{c}2.6^{\mathrm{a}} \\
(1.7-3.0)\end{array}$ & $\begin{array}{c}2.4^{\mathrm{a}} \\
(1.3-3.3)\end{array}$ & $\begin{array}{l}1.2^{\mathrm{b}} \\
(0.4-2.1)\end{array}$ & $2.60-3.30$ \\
\hline Globulin (g/dL) & $\begin{array}{c}5.7^{\mathrm{a}} \\
(3.2-10.6)\end{array}$ & $\begin{array}{c}7.9^{\mathrm{a}} \\
(4.54-13.71)\end{array}$ & $\begin{array}{c}8.1^{\mathrm{a}} \\
(3.1-14.3)\end{array}$ & $2.70-4.40$ \\
\hline Ratio A/G (g/dL) & $\begin{array}{c}0.52^{\mathrm{a}} \\
(0.25-0.85)\end{array}$ & $\begin{array}{c}0.33^{\mathrm{a}} \\
(0.14-0.58)\end{array}$ & $\begin{array}{c}0.15^{\mathrm{b}} \\
(0.13-0.17)\end{array}$ & $0.50-1.30$ \\
\hline
\end{tabular}

USC - Urine Sediment Culture *Values described by Kaneko, Harvey and Bruss (1997). Equal letters on the line do not differ by Kruskal-Wallis or Dunn's test (significance: p-value $<0.05$ ). Control: group of uninfected dogs; Infected, Negative USC: infected dogs with negative urine sediment cultures; Infected, Positive USC: infected dogs with positive urine sediment cultures.

Table 2. Biochemical values and number of clinical signs of dogs of the control group; group of dogs infected with Leishmania sp., but having negative urine sediment cultures; and group of dogs infected with Leishmania sp., with positive urine sediment cultures 


\begin{tabular}{|c|c|c|c|c|c|c|c|c|}
\hline \multirow[b]{2}{*}{$\begin{array}{l}0 \\
\stackrel{0}{0} \\
\stackrel{0}{0}\end{array}$} & \multirow[b]{2}{*}{ 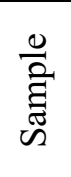 } & \multicolumn{6}{|c|}{ Biochemical Parameters / Normal Values / Unit } & \multirow[b]{2}{*}{$\begin{array}{l}\text { Number } \\
\text { of Clinical } \\
\text { signs }\end{array}$} \\
\hline & & $\begin{array}{c}\text { Urea } \\
21.4-59.9 \\
\mathrm{mg} / \mathrm{dL}\end{array}$ & $\begin{array}{c}\text { Creatinine } \\
0.5-1.5 \\
\mathrm{mg} / \mathrm{dL}\end{array}$ & $\begin{array}{c}\text { Protein } \\
5.4-7.1 \\
\mathrm{~g} / \mathrm{dL}\end{array}$ & $\begin{array}{c}\text { Albumin } \\
2.6-3.3 \\
\mathrm{~g} / \mathrm{dL}\end{array}$ & $\begin{array}{c}\text { Globulin } \\
2.7-4.4 \\
\mathrm{~g} / \mathrm{dL}\end{array}$ & $\begin{array}{c}\mathrm{A} / \mathrm{G} \\
0.5-1.3 \\
\mathrm{~g} / \mathrm{dL}\end{array}$ & \\
\hline \multirow{10}{*}{ 苞 } & 1 & 17.90 & 1.40 & 7.05 & 2.98 & 4.07 & 0.73 & 0 \\
\hline & 2 & 28.84 & 1.03 & 9.13 & 2.63 & 6.50 & 0.40 & 0 \\
\hline & 3 & 37.17 & 1.01 & 13.40 & 2.79 & 10.61 & 0.26 & 0 \\
\hline & 4 & 59.23 & 1.02 & 7.10 & 2.72 & 4.38 & 0.62 & 0 \\
\hline & 5 & 175.45 & 1.87 & 6.0 & 2.76 & 3.24 & 0.85 & 0 \\
\hline & 6 & 31.98 & 1.11 & 7.03 & 2.64 & 4.39 & 0.60 & 0 \\
\hline & 7 & 44.73 & 0.89 & 11.24 & 2.69 & 8.55 & 0.31 & 0 \\
\hline & 8 & 35.45 & 1.02 & 6.97 & 2.68 & 4.29 & 0.62 & 0 \\
\hline & 9 & 31.91 & 0.81 & 6.99 & 2.64 & 4.35 & 0.61 & 0 \\
\hline & 10 & 31.42 & 0.89 & 8.25 & 1.65 & 6.60 & 0.25 & 0 \\
\hline \multirow{15}{*}{ 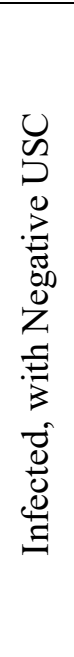 } & 1 & 283 & 2.90 & 9.61 & 2.92 & 6.69 & 0.44 & 1 \\
\hline & 2 & 76.00 & 1.10 & 15.11 & 1.88 & 13.23 & 0.14 & 8 \\
\hline & 3 & 23.90 & 0.60 & 15.97 & 2.26 & 13.71 & 0.16 & 7 \\
\hline & 4 & 33.20 & 0.80 & 13.26 & 2.11 & 11.15 & 0.19 & 4 \\
\hline & 5 & 34.60 & 0.90 & 14.19 & 3.30 & 10.89 & 0.30 & 6 \\
\hline & 6 & 42.70 & 1.10 & 12.68 & 3.06 & 9.62 & 0.32 & 3 \\
\hline & 7 & 55.70 & 1.50 & 8.96 & 3.30 & 5.66 & 0.58 & 1 \\
\hline & 8 & 28.90 & 1.10 & 10.02 & 3.30 & 6.72 & 0.49 & 3 \\
\hline & 9 & 30.36 & 0.88 & 10.55 & 1.68 & 8.87 & 0.19 & 8 \\
\hline & 10 & 37.63 & 0.52 & 7.90 & 2.20 & 5.7 & 0.39 & 7 \\
\hline & 11 & 66.36 & 1.29 & 9.04 & 3.30 & 5.74 & 0.57 & 1 \\
\hline & 12 & 11.71 & 0.62 & 6.59 & 1.59 & 5 & 0.32 & 7 \\
\hline & 13 & 27.98 & 1.05 & 6.06 & 1.52 & 4.54 & 0.33 & 7 \\
\hline & 14 & 53.1 & 0.94 & 6.56 & 1.75 & 4.81 & 0.36 & 7 \\
\hline & 15 & 38.7 & 0.55 & 6.82 & 1.33 & 5.49 & 0.24 & 6 \\
\hline \multirow{5}{*}{ 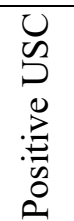 } & 1 & 31.0 & 1.20 & 9.11 & 1.20 & 7.91 & 0.15 & 4 \\
\hline & 2 & 28.0 & 0.80 & 16.41 & 2.12 & 14.29 & 0.15 & 10 \\
\hline & 3 & 37.4 & 0.60 & 3.52 & 0.42 & 3.1 & 0.13 & 12 \\
\hline & 4 & 27.5 & 0.58 & 8.47 & 0.99 & 7.48 & 0.13 & 8 \\
\hline & 5 & 217.0 & 1.36 & 8.88 & 1.32 & 7.56 & 0.17 & 5 \\
\hline
\end{tabular}

USC - Urine Sediment Culture. Control: group of uninfected dogs; Infected with Negative USC: infected dogs with negative urine sediment; Positive USC: infected dogs with positive urine sediment cultures. Bold - biochemical values abnormal when compared to those described by Kaneko, Harvey and Bruss (1997).

In evaluating the number of clinical signs in groups I and II, it was observed that dogs with the urinary parasite presented with means $7.8 \pm 3.3$ higher than those of the infected non-urine Leishmania sp. dogs; $5.1 \pm 2.6$. However, no significant difference was observed ( $p$-value $=0.12$, Mann-Whitney test).

Histopathological analyses detected the following alterations in the kidney: hydropic degeneration, formation of hyaline casts, thickened Bowman's capsule, thickening of the tubular capsule, fibrosis, tubular atrophy, and tubular dilatation (Figures 2A, B, C, and D).
All animals examined had at least one kidney alteration, and were in hydropic degeneration, with thickened Bowman's capsule and thickening of the tubular capsule detected in all dogs with positive urinary sediments (Table 3 ). However, no significant difference was observed in these renal changes, between the groups.

The positive dogs also presented with inflammatory infiltrates in the kidney and bladder urinary sediments (Figures 3A and B). All presented predominance of macrophages and lymphocytes, and one showed a small amount of plasma cells (Table 4). 

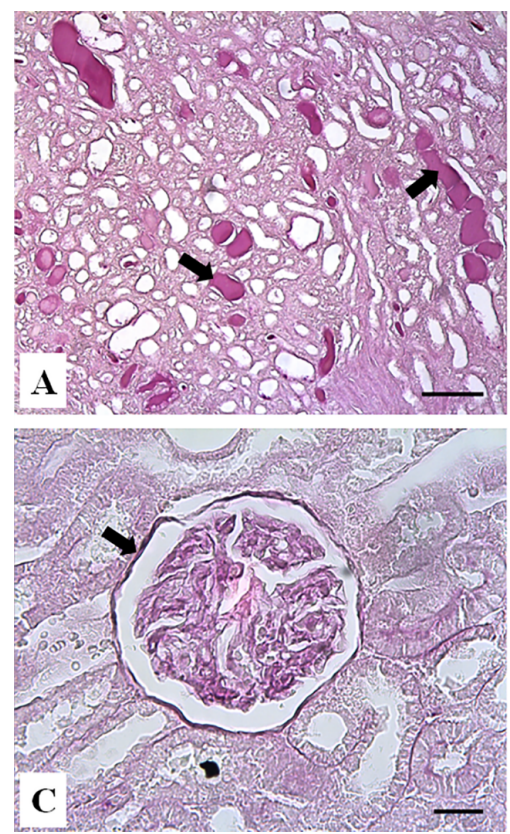
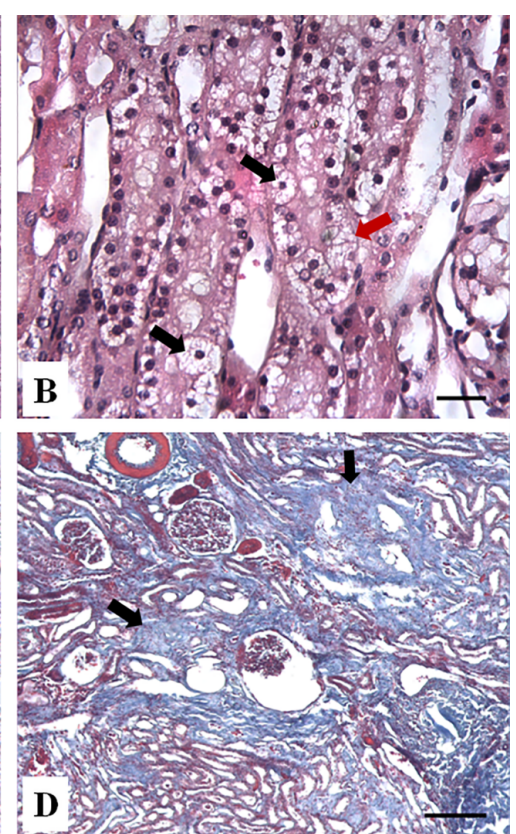

Figure 2. Renal histopathology of dogs positive for Leishmania sp. in urine sediment cultures.

A - Hyaline casts. Masson trichrome staining, Bar $=100 \mu \mathrm{m}$; B - Hydropic degeneration (black arrows) and tubular necrosis (red arrow), HE staining, Bar $=20 \mu \mathrm{m} ; \mathrm{C}-$ Thickening of the Bowman's capsule, PAS staining, Bar $=20 \mu \mathrm{m}$; D Increased connective tissue in the interstitial, intertubular and periglomerular regions, Masson trichrome staining, Bar = $100 \mu \mathrm{m}$.

Table 3. Number and percentage of dogs of the control group; group of dogs infected with Leishmania sp., with negative urine sediment cultures; and group of dogs infected with Leishmania sp., with positive urine sediment cultures, which presented degenerative alterations in renal tissue

\begin{tabular}{lcccc}
\hline \multirow{2}{*}{ Degenerative alterations } & \multirow{2}{*}{ Control } & $\begin{array}{c}\text { Infected, Negative } \\
\text { USC }\end{array}$ & $\begin{array}{c}\text { Infected, } \\
\text { Positive USC }\end{array}$ & \multirow{2}{*}{ Total } \\
\cline { 2 - 5 } & $\mathrm{n}=10(\%)$ & $\mathrm{n}=15(\%)$ & $\mathrm{n}=5(\%)$ & $\mathrm{n}=30(\%)$ \\
\hline Hydropic Degeneration & $5(50)$ & $11(73.3)$ & $5(100)$ & $21(70.0)$ \\
Formation of Hyaline Casts & $7(67)$ & $9(60)$ & $4(80)$ & $20(67.0)$ \\
Thickening of the Bowman's Capsule & $10(100)$ & $9(60)$ & $5(100)$ & $24(80.0)$ \\
Thickening of the Tubular Capsule & $7(67)$ & $9(60)$ & $5(100)$ & $21(70.0)$ \\
Fibrosis & $8(83)$ & $12(80)$ & $4(80)$ & $24(80.0)$ \\
Tubular Atrophy & $2(17)$ & $9(60)$ & $2(40)$ & $13(43.3)$ \\
Tubular Dilatation & $3(33)$ & $3(20)$ & $2(40)$ & $8(26.7)$ \\
\hline
\end{tabular}

USC - Urine Sediment Culture. Control: group of uninfected dogs; Infected with Negative USC: infected dogs with negative urine sediment cultures; Infected with Positive USC: infected dogs with positive urine sediment cultures.

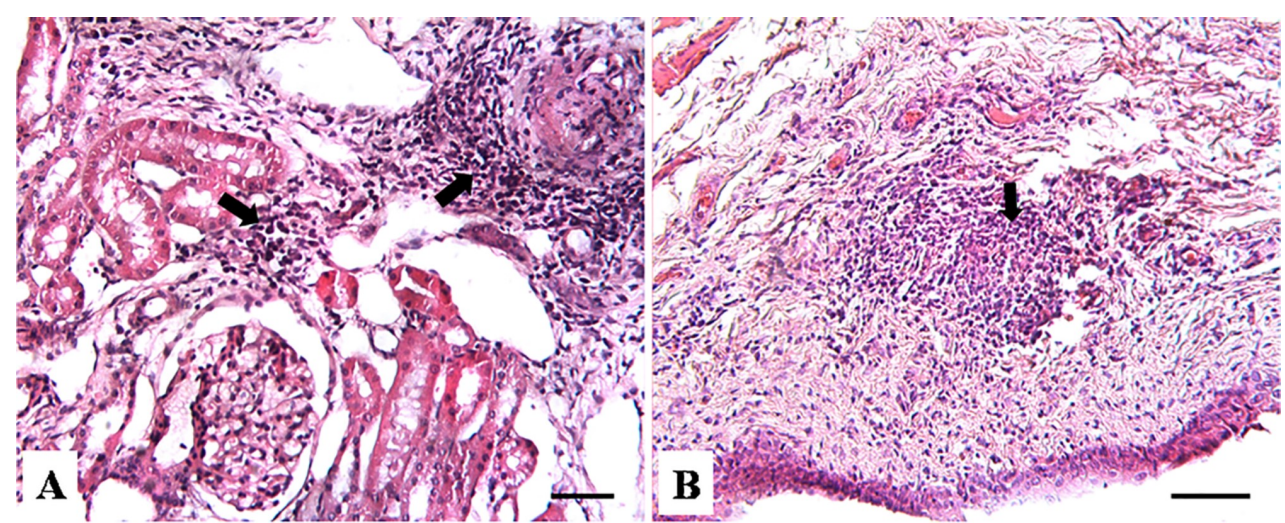

Figure 3. Inflammatory infiltrate in dogs positive for Leishmania sp. in their urinary sediment cultures.

A - kidney, macrophages, and lymphocytes in set (arrow), Bar $=20 \mu \mathrm{m} ; \mathrm{B}-$ bladder, macrophages, and lymphocytes in set (arrow), Bar $=50 \mu \mathrm{m}$. HE staining. 
Table 4. Occurrence, intensity, distribuition, localization, and cellular type of kidney and bladder inflammatory infiltrates in dogs of the control group; group of dogs infected with Leishmania sp., with negative urine sediment cultures; and group of dogs infected with Leishmania sp., with positive urine sediment cultures

\begin{tabular}{|c|c|c|c|c|c|c|}
\hline \multirow{2}{*}{$\begin{array}{l}\text { Inflammatory } \\
\text { Infiltrate }\end{array}$} & \multicolumn{2}{|c|}{ Control } & \multicolumn{2}{|c|}{$\begin{array}{c}\text { Infected, } \\
\text { Negative USC }\end{array}$} & \multicolumn{2}{|c|}{$\begin{array}{c}\text { Infected, } \\
\text { Positive USC }\end{array}$} \\
\hline & Kidney & Bladder & Kidney & Bladder & Kidney & Bladder \\
\hline \multicolumn{7}{|l|}{ Occurrence } \\
\hline Absent & 2 & 4 & 2 & 9 & 0 & 0 \\
\hline Present & 8 & 6 & 13 & 6 & 5 & 5 \\
\hline \multicolumn{7}{|l|}{ Intensity } \\
\hline Minimum & 6 & 3 & 9 & 6 & 2 & 3 \\
\hline Medium & 2 & 3 & 2 & 0 & 3 & 2 \\
\hline Moderate & 0 & 0 & 2 & 0 & 0 & 0 \\
\hline \multicolumn{7}{|l|}{ Distribution } \\
\hline Focal & 6 & 4 & 8 & 6 & 3 & 3 \\
\hline Multifocal & 2 & 1 & 2 & 0 & 2 & 2 \\
\hline Diffuse & 0 & 1 & 3 & 0 & 0 & 0 \\
\hline \multicolumn{7}{|l|}{ Localization } \\
\hline Perivascular & 7 & 6 & 8 & 4 & 5 & 5 \\
\hline Intertitial & 8 & 2 & 12 & 2 & 5 & 0 \\
\hline Periglomerular* & 6 & - & 10 & - & 5 & - \\
\hline Mucosal** & - & 5 & - & 4 & - & 5 \\
\hline Muscular** & - & 3 & - & 3 & - & 2 \\
\hline \multicolumn{7}{|l|}{ Cellular Type } \\
\hline Macrophages & 8 & 6 & 13 & 6 & 5 & 5 \\
\hline Lymphocytes & 7 & 5 & 11 & 5 & 5 & 5 \\
\hline Neutrophils & 0 & 1 & 0 & 0 & 0 & 0 \\
\hline Plasma cells & 2 & 1 & 4 & 0 & 1 & 0 \\
\hline
\end{tabular}

*Only for kidney tissue. **Only for bladder tissue. Control: group of uninfected dogs; Infected with Negative USC: infected dogs with negative urinary sediment cultures; Infected with Positive USC: infected dogs with positive urinary sediment cultures.

In both organs (kidney and bladder), the intensity of the infiltrates ranged from minimal to average, and the distribution, focal to multifocal (Table 4). In the dogs which presented with Leishmania sp. in their urinary sediment, renal inflammatory infiltrates were located in all regions (interstitial, perivascular, and periglomerular). In bladder tissue, inflammatory infiltrates were present more often in the mucous layer, and mainly composed of macrophages and lymphocytes, and to a lesser extent, neutrophils and plasma cells (Table 4). The infiltrates of plasma cells and neutrophils, when present, presented a small number of cells.

No significant difference was observed among the three groups upon evaluating occurrence, intensity, distribution, location, and kidney tissue inflammatory infiltrate cell type. However, the presence of Leishmania sp. in urinary sediments was significantly related to the occurrence, intensity, and distribution of inflammatory infiltrates in bladder tissues (Table 5 and Fig. 4). No significant difference was observed in the location and cell type of the bladder inflammatory infiltrates, between the three groups. There was also no significant difference in degenerative kidney changes between the infected urine-negative animals and infected urine-positive animals (Table 5). 
Table 5. Number of dogs in the group infected with Leishmania sp., with negative urine sediment cultures, and the group of dogs infected with Leishmania sp., with positive urine sediment cultures, in the presence or absence of kidney and bladder histopathological alterations.

\begin{tabular}{|c|c|c|c|c|c|}
\hline \multirow[b]{2}{*}{ Organ } & \multirow[b]{2}{*}{ Histopathological alteration } & \multirow[b]{2}{*}{ Classification } & \multicolumn{2}{|c|}{ Infected Dogs $(n=20)$} & \multirow{2}{*}{$\begin{array}{c}\text { p-value } \\
\text { Two-tailed }\end{array}$} \\
\hline & & & Negative Urine & $\begin{array}{l}\text { Positive } \\
\text { Urine }\end{array}$ & \\
\hline \multirow{16}{*}{ Kidney } & \multirow{2}{*}{ Inflammatory Infiltrate } & Absent & 2 & 0 & \multirow{2}{*}{1.0000} \\
\hline & & Present & 13 & 5 & \\
\hline & \multirow{2}{*}{ Hydropic Degeneration } & Absent & 4 & 0 & \multirow{2}{*}{0.5304} \\
\hline & & Present & 11 & 5 & \\
\hline & \multirow{2}{*}{ Formation of Hyaline Casts } & Absent & 6 & 1 & \multirow{2}{*}{0.6126} \\
\hline & & Present & 9 & 4 & \\
\hline & \multirow{2}{*}{ Thickening of the Bowman's Capsule } & Absent & 6 & 0 & \multirow{2}{*}{0.2604} \\
\hline & & Present & 9 & 5 & \\
\hline & \multirow{2}{*}{ Thickening of the Tubular Capsule } & Absent & 6 & 0 & \multirow{2}{*}{0.2604} \\
\hline & & Present & 9 & 5 & \\
\hline & \multirow{2}{*}{ Fibrosis } & Absent & 3 & 1 & \multirow{2}{*}{1.0000} \\
\hline & & Present & 12 & 4 & \\
\hline & \multirow{2}{*}{ Tubular Atrophy } & Absent & 6 & 3 & \multirow{2}{*}{0.6169} \\
\hline & & Present & 9 & 2 & \\
\hline & \multirow{2}{*}{ Tubular Dilatation } & Absent & 12 & 3 & \multirow{2}{*}{0.5598} \\
\hline & & Present & 3 & 2 & \\
\hline \multirow{2}{*}{ Bladder } & \multirow{2}{*}{ Inflammatory Infiltrate } & Absent & 9 & 0 & \multirow{2}{*}{$0.0379 *$} \\
\hline & & Present & 6 & 5 & \\
\hline
\end{tabular}

*Significant difference (p-value $<0.05$ ) in Fisher's exact test.

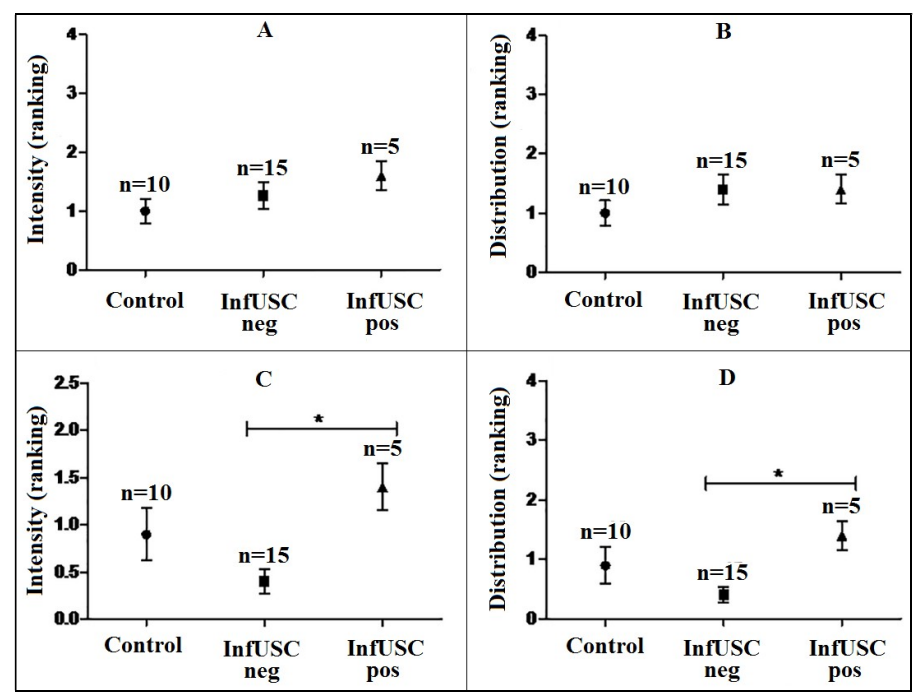

Figure 4. Mean and standard error of the intensity and distribution of the kidney and bladder tissue inflammatory infiltrates.

A - Intensity of inflammatory infiltrate in the kidney; B - Distribution of inflammatory infiltrate in the kidney; C Intensity of inflammatory infiltrate in the bladder; D - Distribution of inflammatory infiltrate in the bladder. ${ }^{*}$ p-value $<$ 0.05 (Kruskal-Wallis' and Dunn's tests). Control: group of uninfected dogs; Infected with negative USC: infected dogs with negative urinary sediment cultures; Infected with positive USC: infected dogs with positive urinary sediment cultures.

\section{DISCUSSION}

Some studies have reported the viability of Leishmania sp. in urinary sediment in both dogs and humans (MENDONÇA; BATISTA; ALVES, 2015b; MEBRAHTU et al., 1993; RIERA; VALADARES, 1996). However, this is the first study to report investigating the possible causes of the presence of Leishmania sp. in the urine of VL dogs.

Of the 30 dogs in which kidney and bladder imprints were performed, only one was positive in the bladder, with none in the kidney. The positive imprint dog also had Leishmania sp. in its urine, 
Evaluation of the serum...

suggesting that Leishmania sp. reaches the urine through the bladder. Additionally, a study by Santos et al. (2013) observed immunostained Leishmania sp. in $32 \%$ of the bladder samples, and in only $8 \%$ of the kidney samples.

The severe hypoalbuminemia in dogs with urine Leishmania sp. suggests that the renal lesions were sufficiently severe to ochestrate albumin leakage (BASTOS; BREGMAN; KIRSZTAJN, 2010). According to Manna et al. (2008), renal alterations such as glomerulonephritis, interstitial nephritis, and deposition of immunocomplexes, may lead to a decrease in peritubular perfusion, with consequent macromolecule passage, justified as loss of albumin through the urinary system. Increased albumin passage through the kidneys occurs when there are lesions in this organ, with increased permeability (RUSSO; BAKRIS; COMPER, 2002). This may justify the passage of Leishmania sp. into urine, since albumin is considerably large and cannot be filtered through an unaltered kidney (RUSSO; BAKRIS; COMPER, 2002).

However, the presence of the parasite in urine had no relationship with kidney failure, as indicated by an increase in serum urea and creatinine. This was proven by the results of the urinary sediment culture and biochemical tests, since four of the five animals with Leishmania sp. growth in their urinary sediment cultures presented with normal serum urea and creatinine concentrations, and only one presented with a high serum urea concentration; therefore, there was no renal failure in the dogs of this group.

An elevated urea concentration cannot solely characterize renal failure, since urea concentration is affected by extra-renal factors such as high protein intake and prolonged fasting. It should be evaluated alongside the creatinine concentration, as it is more specific than urea in the analysis of renal function, characterized by renal insufficiency; both creatinine and urea are increased in blood circulation (LOPES; BIONDO; SANTOS, 2007).

Although urea and serum creatinine quantification revealed no renal insufficiency in dogs with positive urine tests, all five presented histopathological lesions in their kidneys. Furthermore, serum albumin levels of all five were very low and four of them showed formation of hyaline casts in renal tubules, attributable to lesions in these organs, with increased vascular permeability and consequent loss of protein through kidney tubules.
BATISTA et al.

The occurrence of renal lesions without alterations in serum creatinine and urea concentrations may be due to recent infection, and consequently low intensity of lesions (ALVES et al., 2013). Hence, the possibility of Leishmania sp. reaching urine through the kidneys cannot be ruled out because dogs with Leishmania sp. in their urine could be carriers of a recent infection with lesions, without decreased glomerular filtration rates. The chronic character of the renal changes in CVL is evidenced by the increased serum, urea, and creatinine. However, the increase of these biochemical parameters occurs only after deposition of immunocomplexes in the kidneys (SOUSA et al., 2011 ) and considerable loss of approximately $75 \%$ of the nephrons of both kidneys (LANIS et al., 2008).

Although there is the possibility of the passage of Leishmania sp. through the kidneys, we found more evidence that the parasite reaches urine through the bladder. In addition to the evidence presented by Santos et al. (2013), who found a much higher percentage of Leishmania sp. immunostained in the bladder compared to the kidney, we detected a positive bladder imprint in a dog having the parasite in its urinary sediment. In addition, we observed that the intensity and distribution of inflammatory infiltrates in the bladder of dogs presenting with Leishmania sp. in urine were significantly more severe in relation to infected dogs having no parasites in their urinary sediment. Hypoalbuminemia might play a role, as it increases vascular permeability.

\section{CONCLUSION}

The presence of Leishmania sp. in urine was related to the low concentration of serum albumin and the high degree of bladder lesions. This is the first study to report the occurrence of Leishmania sp. in a bladder imprint. This finding shows that histopathological lesions in the bladder are caused by the presence of the parasite. Further, in more intense bladder injuries, Leishmania sp. reaches the urine. Finally, CVL can be diagnosed using a urine sediment culture.

\section{ACKNOWLEDGMENTS}

We would like to thank Editage (www.editage.com) for English language editing. 
RESUMO: O estabelecimento visceral de Leishmania infantum em cães pode resultar em lesões nos tecidos dos rins e da bexiga, favorecendo a chegando do parasito até a urina. Portanto, este estudo teve como objetivo investigar a presença de Leishmania sp. em sedimentos urinários e correlacionar os resultados com os achados de quantificações bioquímicas séricas e histopatologia de rim e bexiga. Trinta cães com Nested-Reação em Cadeia da Polimerase (PCR) negativa para E. canis foram utilizados no experimento e foram divididos em três grupos: grupo controle (10 cães), negativos para leishmaniose e sem alterações clínicas; grupo I (15 cães), com leishmaniose, mas sem Leishmania sp. na urina; e grupo II (5 cães), com leishmaniose e com Leishmania sp. na urina. Todos os animais foram submetidos a diagnóstico clínico, sorológico e parasitológico para leishmaniose, exames bioquímicos e histopatologia de rim e bexiga. O parasito foi detectado no imprimt de bexiga de um cão do grupo II. Os cães do grupo II apresentaram concentrações muito baixas de albumina, baixa relação albumina/globulina e lesões nos rins e na bexiga. Nos rins, foram detectadas degeneração hidrópica, espessamento da cápsula de Bowman e espessamento da cápsula tubular, em todos os cães com sedimento urinário positivo. No entanto, nenhuma diferença significativa nessas alterações renais foi observada entre os grupos. A intensidade e a distribuição dos infiltrados inflamatórios da bexiga foram significativamente (p-valor $<0,05$, testes de Kruskal-Wallis e Dunn) maiores nos cães do grupo II, em comparação com a dos outros grupos. A presença de Leishmania sp. na urina de cães infectados parece estar relacionada a baixa concentração sérica de albumina e a lesões mais graves na bexiga.

PALAVRAS-CHAVE: Histopatologia. Leishmaniose. Bioquímica sérica. Urina.

\section{REFERENCES}

ALBUQUERQUE, B. C. N. C.; MAIA, F. C. L., DA SILVA JÚNIOR, V. A., LIMA, A. M. A., ALBUQUERQUE, E. R. C., PIMENTEL, D. S., ALVES, L. C. Alterações estruturais em rins de caninos naturalmente infectados por Leishmania (Leishmania) chagasi. Revista Brasileira Ciência Veterinária, v. 5 , n. 1, p. 3-5, 2008. https://doi.org/10.4322/rbcv.2014.187

ALVES, G. B. B.; SILVA, L. S.; BATISTA, J. F.; CAMPOS, A. P.; PRIANTI MG, COSTA, F. A. L. The sero-conversion and evaluation of renal alterations in dogs infected by Leishmania (infantum) chagasi. Revista do Instituto de Medicina Tropical de São Paulo, v. 55, n. 2, p. 105-12, 2013.

http://dx.doi.org/10.1590/S0036-46652013000200007

ARESU, L.; BENALI, S.; FERRO, S.; VITTONE, V.; GALlO, E.; BROVIDA, C.; CASTAGNARO, M. Light and Electron Microscopic Analysis of Consecutive Renal Biopsy Specimens From Leishmania-Seropositive Dogs. Veterinary Pathology, v. 50, n. 5, p. 753-760, 2013. doi: 10.1177/0300985812459336. Epub 2012 Sep 6

BASTOS, M. G.; BREGMAN, R.; KIRSZTAJN, G. M. Doença renal crônica: frequente e grave, mas também prevenível e tratável. Revista da Associação Médica Brasileira, v. 56, n. 2, p. 248-53, 2010. http://dx.doi.org/10.1590/S0104-42302010000200028

BULLA, C.; KIOMITAKAHIRA, R.; PESSOA ARAÚJO, J. Jr.; APARECIDA TRINCA, L.; SOUZA LOPES, R.; WIEDMEYER, C. E. The relationship between the degree of thrombocytopenia and infection with Ehrlichia canis in an endemic area. Veterinary Research, v. 35, n. 1, p. 141-6, 2004. DOI: 10.1051/vetres:2003038

CAMARGO, M. H. B.; MORAES, J. R. E.; CARVALHO, M. B.; FERRARO, G. C.; BORGES, V. P. Alterações morfológicas e funcionais dos rins de cães com insuficiência renal crônica. Arquivo Brasileiro de Medicina Veterinária e Zootecnia, v. 58, n. 5, p. 781-7, 2006. http://dx.doi.org/10.1590/S010209352006000500013

CASTRO, I. P.; SOUSA, M. V. C.; MAGALHÃES, G. M.; MUNDIM, A. V.; NOLETO, P. G.; PAULA, M. B. C.; PAJUABA NETO, A. A.; MEDEIROS, A. A. Perfil hepático e protéico em cães com leishmaniose visceral. Bioscience Journal, v. 28, n. 5, p. 799-804, 2012. 
COSTA, F. A. L.; GOTO, H.; SALDANHA, L. C. B.; SILVA, S. M.; SINHORINI, I. L.; SILVA, T. C.; GUERRA, J. L. Histopathologic patterns of nephropathy in naturally acquired canine visceral leishmaniasis. Veterinary Pathology, v. 40, n. 6, p. 677-84, 2003. DOI: 10.1354/vp.40-6-677

COSTA, M. P.; HORTA, R. S.; COURA, F. M.; MOL, J. P. S.; VALENTE, P. C. L. G.; PAES, P. R. O. Bioquímica sérica de cães infectados por Ehrlichia canis, Anaplasma platys e Leishmania sp.. Acta Scientiae Veterinariae, v. 43, n. 1261, p. 1-7, 2015.

DAWSON, J. E.; STALLKNECHT, D. E.; HOWERTH, E. W.; WARNER, C.; BIGGIE, K.; DAVIDSON, W. R.; LOCKHART, J. M.; NETTLES, V. F.; OLSON, J. G.; CHILDS, J. E. Susceptibility of white-tailed deer (Odocoileus virginianus) to infection with Ehrlichia chaffeensis, the etiologic agent of human ehrlichiosis. Journal of Clinical Microbiology, v. 32, n. 11, p. 2725-2728, 1994. PMid:7852563. https://doi.org/10.1128/JCM.32.11.2725-2728.1994

FILHO, N. S.; FERREIRA, T. M. A. F.; COSTA, J. M. L. Envolvimento da função renal em pacientes com leishmaniose visceral (calazar). Revista da Sociedade Brasileira de Medicina Tropical, v. 36, n. 2, p. 217-21, 2003. http://dx.doi.org/10.1590/S0037-86822003000200004

GIUNCHETTI, R. C.; MAYRINKZ, W.; GENAROZ, O.; CARNEIRO, C. M.; CORREAA-OLIVEIRAY, R.; MARTINS-FILHO, O. A.; MARQUES, M. J.; TAFURI, W. L.; REIS, A. B. Relationship between Canine Visceral Leishmaniosis and the Leishmania (Leishmania) chagasi Burden in Dermal Inflammatory Foci. Journal of Comparative Pathology, v. 135, n. 2-3, p. 100-7, 2006. doi: 10.1016/j.jcpa.2006.06.005. Epub 2006 Sep 7

GOMES, L. A.; GOTO, H.; GUERRA, J. L. G.; MINEIRO, A. L. B.; SILVA, S. M. M. S.; COSTA, F. A. L. Lesões renais intersticiais e tubulares na leishmaniose visceral. Revista Portuguesa de Ciência Veterinária, v. 103, n. 567-568, p. 157-63, 2008.

KANEKO, J. J.; HARVEY, J. W.; BRUSS, M. L. Clinical Biochemistry of Domestic Animals. $5^{\text {th }}$ ed. San Diego: Academic Press, 1997. 932p.

LANIS, A. B.; FONSECA, L. A.; ROESLER, T.; ALVES, A.; LOPES, B. Avaliação laboratorial das doenças renais em pequenos animais. Pubvet, v. 2, 2008.

LOPES, S. T. A.; BIONDO, A. W.; SANTOS, A. P. Manual de patologia clínica veterinária. $3^{\mathrm{a}}$ ed. Santa Maria: Universidade Federal de Santa Maria, 2007. 107p.

MANNA, L.; REALE, S.; PICILLO, E.; VITALE, F.; GRAVINO, A. E. Urine sampling for real-time polymerase chain reaction-based diagnosis of canine leishmaniasis. Journal of Veterinary Diagnostic Investigation, v. 20, n. 1, p. 64-7, 2008. DOI: 10.1177/104063870802000112

MEBRAHTU, Y. B.; HENDRICKS, L. D.; OSTER, C. N.; LAWYER, P. G.; PERKINS, P. V.; PAMBA, H.; KOECH, D.; ROBERTS, C. R. Leishmania donovani parasites in the nasal secretions, tonsillopharyngeal mucosa, and urine centrifugates of visceral leishmaniasis patients in Kenya. American Journal of Tropical Medicine and Hygiene, v. 48, n. 4, p. 530-535, 1993. https://doi.org/10.4269/ajtmh.1993.48.530

MENDONÇA, I. L. a; ALVES, M. M. M.; BATISTA, J. F.; ROCHA, F. S. B.; SILVA, E. M. C. Alterações bioquímicas e hematológicas em cães naturalmente infectados por Leishmania (infantum) chagasi. Clínica Veterinária, a. 20, n. 116, p. 78-84, 2015.

MENDONÇA, I. L. b; BATISTA, J. F.; ALVES, L. C. Leishmania (infantum) chagasi in canine urinary sediment. Revista Brasileira de Parasitologia Veterinária, v. 24, n. 1, p. 92-4, 2015.

http://dx.doi.org/10.1590/S1984-29612014086 
MENDONÇA, I. L. b; BATISTA, J. F.; SCHALLIG, H.; CRUZ, M. D. S. P. E.; ALONSO, D. P.; RIBOLLA, P. E. M.; COSTA, D. L.; COSTA, C. H. N. The performance of serological tests for Leishmania infantum infection screening in dogs depends on the prevalence of the disease. Revista do Instituto de Medicina Tropical de Sao Paulo, v. 1, n. 59, e. 39, 2017. doi: 10.1590/S1678-9946201759039.

MENDONÇA, I. L. a; BATISTA, J. F.; WERNECK, G. L.; SOARES, M. R. A.; COSTA, D. L.; COSTA, C. H. N. Serological tests fail to discriminate dogs with visceral leishmaniasis that transmit Leishmania infantum to the vector Lutzomyia longipalpis. Revista da Sociedade Brasileira de Medicina Tropical, v. 50, n. 4, p. 483-488, 2017. doi: 10.1590/0037-8682-0014-2017.

QUEIROZ, N. M. G. P.; ASSIS, J.; OLIVEIRA, T. M. F. S.; MACHADO, R. Z.; NUNES, C. M.; STARKEBUZETTI, W. A. Diagnóstico da Leishmaniose Visceral Canina pelas técnicas de imunoistoquímica e PCR em tecidos cutâneos em associação com a RIFI e ELISA-teste. Revista Brasileira de Parasitologia Veterinária, v. 19, n. 1, p. 34-40, 2010. http://dx.doi.org/10.4322/rbpv.01901006

RIERA, C.; VALLADARES, J. E. Viable Leishmania infantum in Urine and Semen in Experimentally Infected Dogs. Parasitology Today, v. 12, n. 10, p. 412, 1996. https://doi.org/10.1016/0169-4758(96)90062-9

RUSSO, L. M.; BAKRIS, G. L.; COMPER, W. D. Renal Handling of Albumin: A Critical Review of Basic Concepts and Perspective. American Journal of Kidney Diseases, v. 39, n. 5, p. 899-919, 2002. https://doi.org/10.1053/ajkd.2002.32764

SANTOS, J. P.; ALVES, L. C.; RAMOS, R. A. N.; PIMENTEL, D. S.; CARVALHO, G. A.; MONTEIRO, M. F. M.; FAUSTINO, M. A. G. Histological changes and immunolabeling of Leishmania infantum in kidneys and urinary bladder of dogs. Revista Brasileira de Parasitologia Veterinária, v. 22, n. 3, p. 420-423, 2013. http://dx.doi.org/10.1590/S1984-29612013000300017

SANTOS, T. R.; CARREIRA, V. S.; FERRARI, H. F.; MOREIRA, M. A. B.; LUVIZOTTO, M. C. R. Comparison of PCR with stained slides of bone marrow and lymphnodes aspirates with suspect diagnosis for leishmaniasis. Acta Tropica, 140:137-40, 2014. doi: 10.1016/j.actatropica.2014.08.016

SOUSA, M. V. C.; CASTRO, I. P.; MAGALÃES, G. M.; MUNDIM, A.V.; SOARES, N. P.; NOLETO, P. G.; BORGES, A. C.; LIMONGI, J. E.; MEDEIROS, A. A. Níveis séricos de ureia e creatinina em cães naturalmente infectados por Leishmania chagasi. Pubvet, v. 5, 2011. https://doi.org/10.22256/pubvet.v5n12.1078

TISHER, C. C.; BRENNER, B. M. Avaliação das amostras de biópsia de rim. Em: Patologia Renal com Correlações clínico e funcional. $5^{a}$ ed. Philadelphia: Lippincott Company, 1994. 85-115.

YABSLEY, M. J.; NORTON, T. M.; POWELL, M. R.; DAVIDSON, W. R. Molecular and serologic evidence of tick-borne Ehrlichiae in three species of lemurs from St. Catherines Island, Georgia, USA. Journal of Zoo and Wildlife Medicine, v. 35, n. 4, p. 503-509, 2004. http://dx.doi.org/10.1638/03-116. PMid:15732591 